\title{
NAGY INTENZITÁSÚ ULTRAIBOLYA LÉZEREKKEL KELTETT PLAZMÁK KONTRASZTFÜGGŐ ABSZORPCIÓJA ÉS DINAMIKÁJA
}

\author{
Zs. Kovács ${ }^{1,2}$, B. Gilicze ${ }^{2,3, *}$, S. Szatmári'²,3 I. B. Földes ${ }^{1}$ \\ ${ }^{1}$ Wigner Fizikai Kutatóközpont, Nagyenergiás Fizikai Osztály, Budapest H-1121, Magyarország \\ ${ }^{2}$ Szegedi Tudományegyetem Kísérleti Fizikai Tanszék, Szeged H-6720, Magyarország \\ ${ }^{3}$ Szegedi Tudományegyetem Interdiszciplináris Kiválósági Központ, Szeged H-6720, Magyarország \\ * Jelenlegi elérhetöség ELI-ALPS, Szeged H-6728, Magyarország
}

DOI: https://doi.org/10.14232/kvantumelektronika.9.22

\section{Bevezetés}

A mély ultraibolya tartományon $(248 \mathrm{~nm})$ müködő $\mathrm{KrF}$ rendszerek perspektivikus alternatívát nyújtanak nemcsak a tehetetlenségi összetartáson [1], hanem a gyors begyújtáson alapuló [2] fúziós kísérleti sémákhoz is, mint meghajtó lézerek. Ezek az előnyök a rövid hullámhosszból adódó nagyobb behatolási mélységnek (és a megnövekedett abszorpciónak), valamint a parametrikus instabilitások csökkentett hatásának tudhatók be. A rövid impulzusú elrendezések direkt erősítésük révén pedig, tiszta, pikoszekundumos vállaktól mentes impulzusokat tudnak szolgáltatni, lehetőséget teremtve az előimpulzusoktól mentes kölcsönhatási vizsgálatokhoz. Háttér azonban itt is jelen van erősített spontán emisszió formájában, amelynek hatása - mint látni fogjuk - nem elhanyagolható.

Köztudott, hogy az intenzitáskontraszt javítása kedvező hatással bír a magas harmonikusok keltésére, attoszekundumos impulzuskeltésre, izochor fütési mechanizmusokra stb [3,4]. Az elöimpulzusok hatásának csökkentésére különböző kontrasztjavító sémákat fejlesztettek ki. A manapság elérhető $10^{18}-10^{22} \mathrm{Wcm}^{-2}$ intenzitások mellett a kontrasztnak legalább 10 nagyságrendünek kell lennie.

A következőkben bemutatott kísérletünk az első célzott alkalmazása a nemrég bemutatott nemlineáris Fourier-szürőnek mint hatékony kontrasztjavító technikának [5]. Használatával rekord gyorsulást mértünk a $248 \mathrm{~nm}$ hullámhosszon mind kis és nagy rendszámú céltárgyakon, nagy intenzitásokon $\left(1.15 \times 10^{18} \mathrm{~W} \mathrm{~cm}^{-2}\right)$, ahol a relativisztikus hatások még elhanyagolhatók.

\section{Kísérleti módszerek}

Kísérleteinkhez az ultrarövid impulzusokat egy Szatmári-típusú lézerrendszer szolgáltatta [6]. Egy $\mathrm{XeCl}$ excimer által pumpált festéklézer kaszkád 500 fs félértékszélességü 497 nm központi hullámhosszúságú, $200 \mu \mathrm{J}$ energiájú impulzusokat bocsájtott ki, amit egy frekvenciakétszerező kristályon (béta-bárium-borát, $\mathrm{BBO}$ ) való átvezetés éppen a $\mathrm{KrF}$ erősítési sávszélességének a közepére hangol $(248.5 \mathrm{~nm})$. Az így kapott, tiszta, pikoszekundumos vállaktól mentes magimpulzus direkt erősítéssel egy három fokozatból álló, 6 átmenetes lánc végén éri el a végleges $80 \mathrm{~mJ}$ impulzusenergiát. A közelmúltban jelentős fejlesztések történtek a rendszeren. Gilicze és munkatársai az erősítőlánc bővítésén felül sikeresen implementáltak egy új kontrasztjavító eljárást, az ún. nemlineáris Fourier-szürőt [7]. Ez a rendszerben az első pátmenet utáni előleképezésből és a második átmenetet követő maszkolással ill. gázjetben való fókuszálással valósul meg (1.a ábra). A módszerrel kiemelkedően jó, $10^{12}$ intenzitáskontraszt érhető el, használatát mellőzve viszont a kontraszt $5 \times 10^{5}$ értékre csökkent. Így egyedi kísérleti körülmények között több mint 6 nagyságrend különbséggel vizsgáltuk az előimpulzusok hatását az abszorpcióra és a reflektált sugárzás spektrumára. 

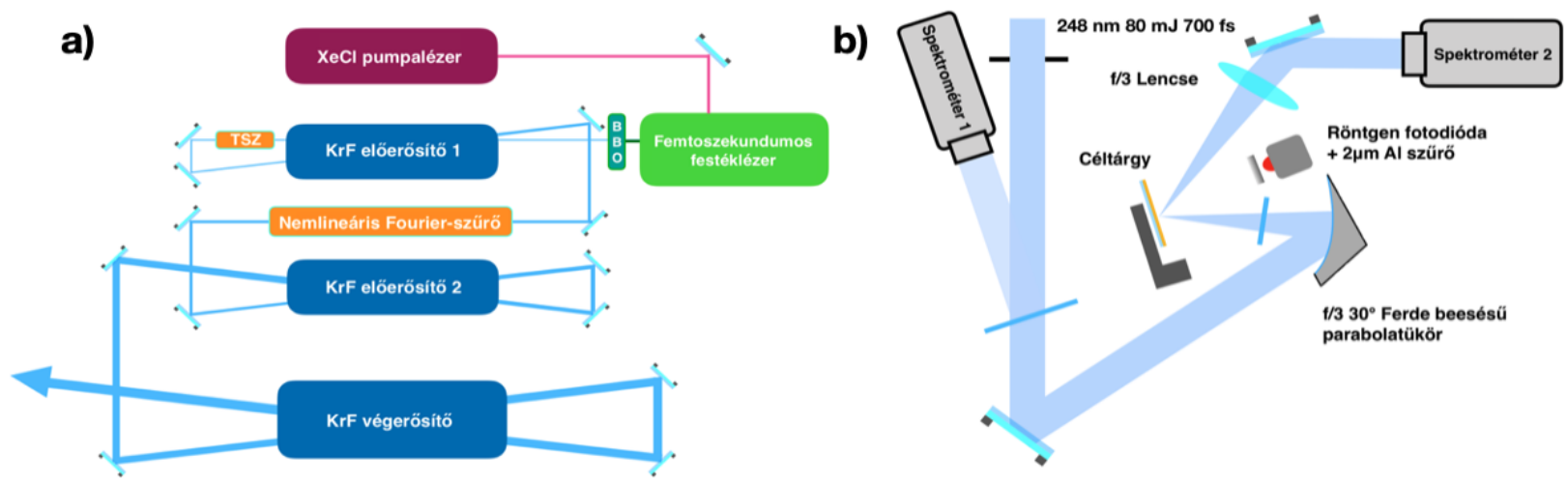

1.ábra. a) A lézerrendszer elvi felépitése, ahol TSZ egy hagyományos térszüröt, BBO pedig a frekvenciakétszerezö kristályt jelöli. b) A kísérleti elrendezés [8,9].

Az autokorrelációs mérésekből a főimpulzus félértékszélessége ( $\left.\operatorname{sech}^{2}\right) 700$ fs-nak adódott és enyhe pozitív $\left(\sim 3.5 \times 10^{-5} \mathrm{fs}^{-2}\right)$ csörppel rendelkezett. A lézer a laboratórium vonatkoztatási rendszere szerint vízszintes polarizációjú volt (P-polarizáció), amelynek kioltási arányát valamelyest rontotta a rendszerbe épített nagy számú optikai elem (7:1). A lézerimpulzusokat vákuumkamrába bevezetve ( $<10^{-5}$ mbar) egy SORL gyártmányú, 30 fokban döntött beesési szögü f/3 parabolatükörrel fókuszáltuk egy enyhén elliptikus foltba. A félértékszélességek rendre $1.85 \pm 0.1 \mu \mathrm{m}$ és $1.95 \pm 0.1 \mu \mathrm{m}$ nek adódtak a függőleges és vízszintes tengelyek mentén. A fókuszfolt eloszlása szerint a lézerenergia több mint $70 \%$-a esett az Airy-függvény központi rendjébe. A Fourier-szürő alkalmazásával az energiakontrasztot 1:80 arányúnak mértük, és a gyenge fókuszálhatósága miatt az erősített spontán emissziós háttér (ESE) fókuszált mérete $1.56 \mathrm{~mm}$ méretü volt. Szürés nélkül az energiakontraszt 1:8 arányra csökkent, valamint az ESE fókuszálhatósága $(\sim 7 \mu \mathrm{m})$ és így intenzitása is jelentősen megnőtt. A továbbiakban a szürővel, valamint a nélküle végzett mérésekre (10 ${ }^{12}$ és $5 \times 10^{5}$ intenzitáskontraszt), nagy és alacsony kontrasztú esetekként hivatkozunk. A stabil müködés biztosítása végett a lézert folytonos $1 \mathrm{~Hz}$-es üzemmódban használtuk, a lövéseket pedig egy szinkronizált redőnyzárral (shutter) választottuk ki. A légmozgásokból eredő fázisfront torzulások kivédése céljából pedig a teljes nyalábutat lefedtük.

A céltárgyak úsztatott üveg hordozóra vákuum-párologtatott, bór és arany (500 nm vastag) rétegek voltak. A minták morfológiai minőségét teljes méretükben profilométerrel ellenőriztük. A mérések szerint a felületi egyenetlenségek sehol sem haladták meg az 50 nanométert, azaz simaságuk legalább $\lambda / 5$. A lézerimpulzusok beesési szöge $45^{\circ}$, így a felületen, valós foltmérettel maximálisan $1.15 \times 10^{18}$ W $\mathrm{cm}^{-2}$ csúcsintenzitást értünk el. Megvédve a céltárgy ablációjából származó lerakódásoktól a parabolatükröt, egy $1 \mathrm{~mm}$ vastagságú suprasil kvarclemezt helyeztünk a minta és a tükör közé. Ez nem befolyásolta érdemben a fókuszálhatóságot, sem a beérkező nyaláb spektrumát. A mintákat a vákuumkamrán belül egy $1.25 \mu \mathrm{m}$ lépésközü xyz céltárgymozgatóval (STANDA 133-373) pozícionáltuk. A mozgató tengelyek stabilitását mechanikus profilométerrel is ellenőriztük. A $4 \mathrm{~cm}$ es mozgatási tartományon minden irányban $\pm 2.5 \mu \mathrm{m}$ szórást mértünk, ami jóval a lézerimpulzusaink $6 \mu \mathrm{m}$-es Rayleigh-hosszán belül maradt. Az intenzitás változtatásához a nyalábútba helyezett blende méretét változtattuk. A diffrakciós effektusokat figyelembe véve, minden nyalábméret esetén megnéztuik a fókuszfolt méretét, így a céltárgyon $55 \mathrm{~mJ}$ és $0.8 \mathrm{~mJ}$ között változott az energia, és három nagyságrendben az intenzitás. A fókuszsík meghatározásához a targeten keltett plazma intenzitásfüggő röntgen-emisszióját használtuk, amit egy $2 \mu \mathrm{m}$ vastag alumíniumszürővel ellátott 
röntgenérzékeny fotodiódával (IRD AXUV-100) detektáltunk. Minden mérési pont értékét 5-10 lövés átlagából számítottuk.

\section{Eredmények és diszkusszió}

A céltárgy reflektivitását (és így az abszorpcióját) a kollimáló lencse és kamraablak transzmissziós veszteségeit figyelembe véve mértük. A reflektált sugárzás éles térbeli kontúrral rendelkezett, így a nem tükörszerü irányba történő szórást kizártuk. A mért reflexió intenzitásfüggése a 2. ábrán látható. Mind arany (a), és bór (b) céltárgyak esetén monoton csökkenést tapasztaltunk növekvő intenzitás mellett. Moderált, alacsonyabb intenzitások $\left(\sim 10^{15} \mathrm{Wcm}^{-2}\right)$ esetén az eredmények egybevágnak korábbi, kutatócsoportunk és Fedosejevs által végzett plazmatükör kísérletekkel [10,11]. A várakozásoknak megfelelően az alacsony kontrasztú esetekben már a kis intenzitásokon megfigyelhető abszorpció jelentősen nagyobb, ám az intenzitás növekedésével, különösen a nagy rendszámú arany esetén a különbség jelentősen csökken, illetve gyakorlatilag megszünik.
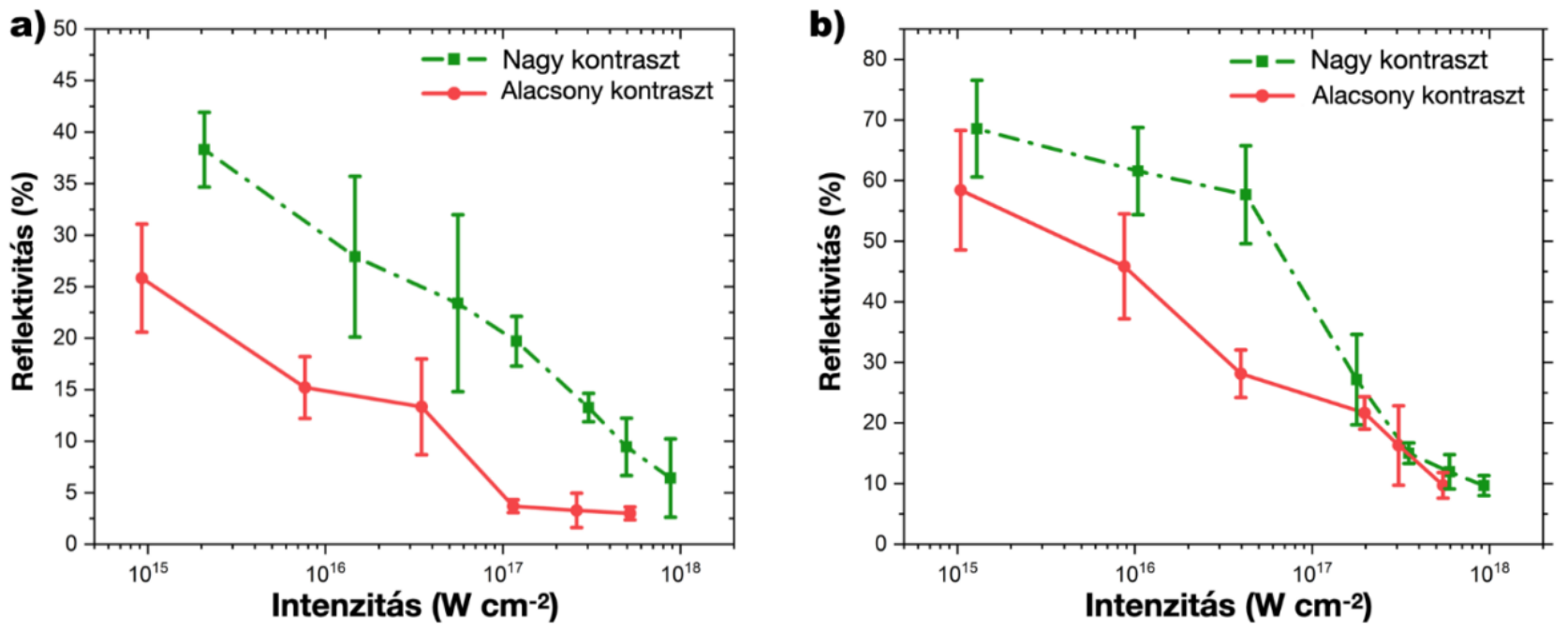

2.ábra. a) arany céltárgy reflektivitása a lézerintenzitás függvényében, ahol a zöld, szaggatott vonal $10^{12}$, a folytonos piros vonal pedig az alacsony $5 \times 10^{5}$ intenzitáskontrasztú esetet jelöli. Ugyanezen mérések bór céltárgyon (b) [8].

A korai, alacsony intenzitású vizsgálatokat Teubner és munkatársai további kísérletekkel folytatták $[12,13]$. Elrendezésükben az általunk használthoz hasonló elvü Szatmári-típusú lézerrendszerrel 109$10^{10}$ intenzitáskontraszt és $10^{17} \mathrm{Wcm}^{-2}$ csúcsintenzitás mellett a lézer 45 fokos beesési szöge esetén az abszorpció meghaladta a 80\%-t, amit a szimulációk nem tudtak megmagyarázni. Elmondható, hogy kis rendszámú céltárgyak esetén eredményeink jó egyezést mutatnak a korábbi megfigyelésekkel. Arany, és különösen az alacsony kontraszt esetén az abszorpció rendkívül nagy, a legnagyobb intenzitásoknál meghaladja a 95\%-t. Tudható, hogy fémek esetén a fotoionizációs küszöb alacsonyabb, így a hosszabb előplazma teret enged nagymértékü inverz fékezési sugárzásnak és egyben hatékony abszorberként is funkcionál. Már a 90-es évek óta tudjuk [14], hogy $248 \mathrm{~nm}$ hullámhosszon már $10^{7} \mathrm{Wcm}^{-2}$ intenzitású, nanoszekundumos előimpulzusok is képesek előplazmát kelteni. Esetünkben ezt a küszöbértéket jelentősen meghaladtuk. Alacsony kontraszt mellett az ESE intenzitása meghaladta a $10^{12} \mathrm{Wcm}^{-2}$ értéket. A repülési időadatok szerint már a kis intenzitású ESE is képes $10^{6} \mathrm{~cm} / \mathrm{s}$ sebességü, táguló plazmafrontot létrehozni [13], így az előplazma skálahossza meghaladhatja akár $\lambda / L=30$ értéket is. A mérési adatok és szimulációk szerint, nagyjából 
$10^{17} \mathrm{Wcm}^{-2}$-ig az ütközéses, afölött pedig az ütközésmentes mechanizmusok dominálnak ebben az esetben. Nagy tisztaságú impulzusok esetén joggal tehetjük fel a kérdést, mi okozza a hasonlóan nagy abszorpciót a csúcsintenzitások környékén. Meredek plazmaprofil esetén mi a meghatározó mechanizmus? Meg kell említenünk, hogy habár impulzusaink szubpikoszekundumosak, 700 fs félértékszélesség és sech ${ }^{2}$ impulzusprofil mellett, a főimpulzus csúcsától már 1 ps távolságban, a felfutó él is képes $10^{14} \mathrm{Wcm}^{-2}$ intenzitást, és így akár $0.1 \lambda$ hosszú plazmát kelteni. Továbbá a 45 fokos beesési szög különösen kedvez a rezonancia-abszorpciónak [15]. Nagy, $10^{18} \mathrm{Wcm}^{-2}$ fölötti intenzitás esetében a Brunel-abszorpció vagy vákuum-fütés dominálhat [16], ami önmagában is adhat több mint $80 \%$ abszorpciót. Mivel az abszorpciós mechanizmusok között nincs éles elválasztó határ, feltételezhetően egyfajta kevert összhatás felelős a teljes abszorpcióért, aminek ellenőrzéséhez további szimulációk szükségesek.

Eredményeinket összevethetjük infravörös lézerekkel végzett kísérletekkel is. Ziener és munkatársai 90 fs és 500 fs hosszúságú CPA lézerekkel több mint 90\%-os abszorpciót értek el $10^{17} \mathrm{Wcm}^{-2}$ intenzitáson, ami a miénkkel hasonló eredmények értelmezhető, különösen akkor, ha számba vesszük a hullámhossz különbségből adódó $I \lambda^{2}$ faktort [17]. Singh és kollégái egy nemrég közölt tanulmányukban alacsony, közepes, valamint nagy kontrasztú 30 fs-os lézerimpulzusok reflektivitását vizsgálták közel $10^{19} \mathrm{~W} \mathrm{~cm}^{-2}$ intenzitáson [4]. Az általunk elért legnagyobb érték 1.15 $\times 10^{18} \mathrm{~W} \mathrm{~cm}^{-2}$ megfeleltethető az I $\lambda^{2}$ skálázódás szerint az ő legalacsonyabb kezdőintenzitásukkal, ám esetünkben valamelyest nagyobb volt az abszorpció, amit a rövid hullámhossz plazmabéli mélyebb behatolási mélységével magyarázunk.

Talán legérdekesebb eredményünk a reflektált impulzusok megfigyelt spektrális eltolódása. Ezek értékei $0.08 \mathrm{~nm}$ és $0.65 \mathrm{~nm}$ között változtak az intenzitás és a kontraszt függvényében. Minden esetben kék-eltolódást tapasztaltunk, azaz a kritikus elektronsürüségü plazmafront a céltárgy normálisa szerint kifelé, a lézer irányával szemben tágult. Ennek sebességére az egyszerü, nemrelativisztikus Doppler-formulából következtetünk:

$$
v=\frac{c}{2 \cos \theta} \frac{\Delta \lambda}{\lambda}
$$

Állandó, 45 fokos beesés esetén a sebesség az eltolódás mértékével arányos (3. ábra).

Egyértelmü, hogy a tiszta impulzusok kedvező hatással bírnak a tágulás sebességére, de minden esetben telítést tapasztalunk $10^{17} \mathrm{Wcm}^{-2}$ felett, bór esetében pedig a csúcsintenzitásnál alacsony kontraszt esetén a tendencia megfordulni látszik. A maximális sebesség bór céltárgyon volt megfigyelhető, mégpedig $5.6 \times 10^{7} \mathrm{cms}^{-1}$ a nagy kontrasztú esetben, ami $1.5 \times 10^{18} \mathrm{~ms}^{-2}$ gyorsulásnak feleltethető meg. Figyelemre méltó, hogy ez az érték jelentősen (közel négyszer) magasabb, mint a korábbi KrF rendszerekkel végzett hasonló kísérletekben [18], ahol a kontraszt jelentősen alacsonyabb volt $\left(10^{8}-10^{9}\right)$. Mivel az ultraibolya tartományban az általunk alkalmazott intenzitás még nem relativisztikus, ezért a maximális intenzitás esetére Wilks és Kruer gondolatmenetét alkalmazhatjuk [19]. A Brunel-abszorpció formálisan:

$$
A=\frac{I_{a b s}}{I_{0}}=8 \frac{v_{o s c}}{c} \sin ^{3} \theta
$$

A felületi elektronok vosc oszcillációs sebessége kifejezhető, mint:

$$
v_{\text {osc }}=\frac{e|E|}{m \omega}=\frac{e}{m \omega} \sqrt{\frac{8 \pi I_{0}}{c}}
$$



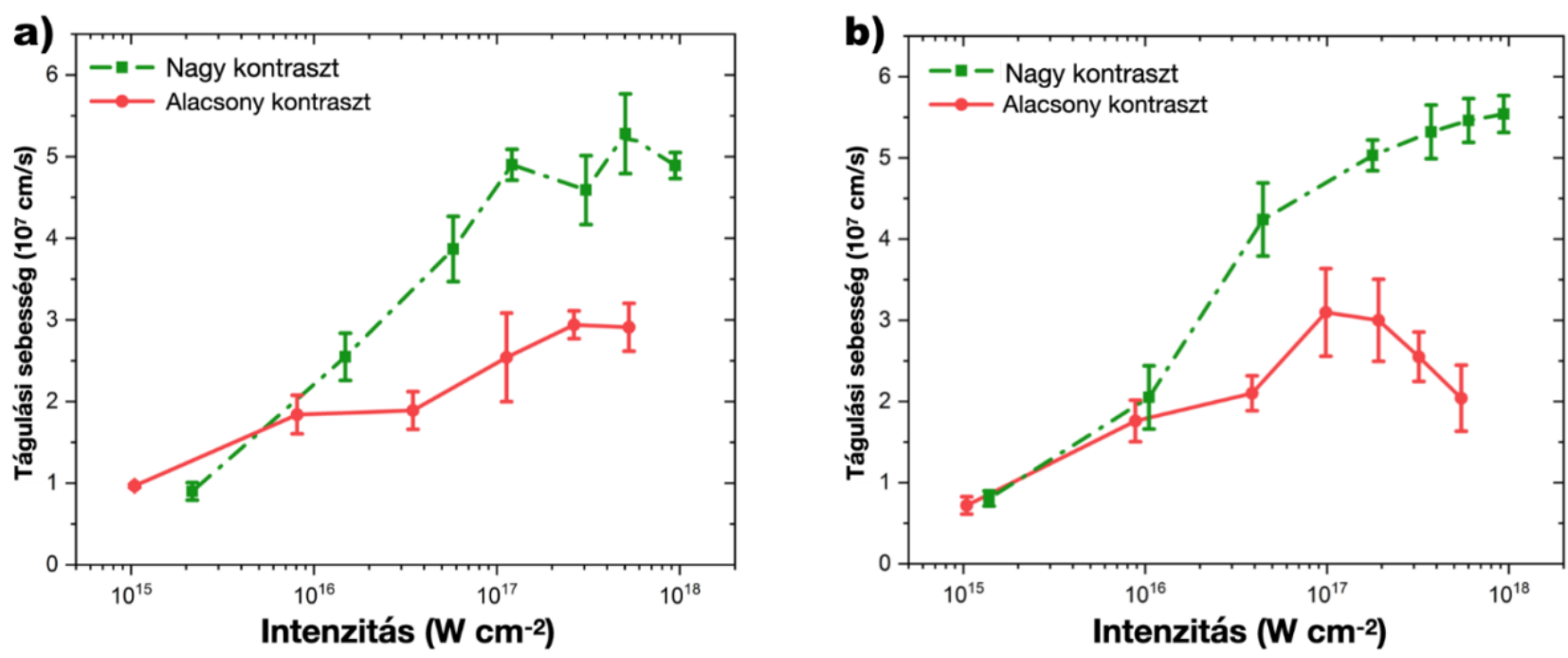

3.ábra. A reflektáló plazmaréteg tágulási sebességei intenzitás és kontraszt függvényében arany (a) és bór (b) céltárgyakról [8].

Az ennek a sebességnek megfelelő forró elektron-hőmérséklet $11.5 \mathrm{keV}$ és az ebből származtatott ion-akusztikus sebesség $7.3 \times 10^{7} \mathrm{~cm} \mathrm{~s}^{-1}$. Az tágulás irányával ellentétes, a lézerfény nyomásából eredő sebességkomponens megbecsülhetö:

$$
v_{l p}=\frac{p}{\rho \delta} \tau \approx 1.1 \times 10^{7} \frac{\mathrm{cm}}{\mathrm{s}}
$$

Itt $p \sim 330$ Mbar fénynyomást feltételeztünk, ahol $\rho$ a sürüséget, $\tau$ pedig a lézerimpulzus hosszának a felét (350 fs), jelöli. Becsült skálahossznak a $\delta=\lambda / 5$ értéket adtuk meg. A kétféle következtetett sebesség különbsége jól visszaadja a plazma spektrális mérésekből származtatott tágulási sebességét. Ez az eredmény is azt sejteti, hogy Fourier-szürő alkalmazása esetén a plazmaprofil már elég meredek a Brunel-mechanizmus érvényesüléséhez. Az alacsony kontraszt esetén tapasztalt kisebb tágulási sebességek magyarázata is ehhez kapcsolódik. A sürü előplazma és nagy skálahossz miatt a lézer elektromos tere és a kritikus réteg kölcsönhatása gyengébb, valamint jelentős energiaveszteséget szenvedhet az impulzus mire az reflexiót szenved.

\section{4.Összefoglalás}

Először demonstráltuk sikeresen a nemlineáris Fourier-szürő alkalmazását intenzív lézer-plazma kísérletben. Így egyedi körülmények között, extrém nagy intenzitáskontraszt mellett több mint 90\% abszorpciót mértünk kis (bór) és nagy (arany) rendszámú céltárgyakon. Az elért nagy, de még nem relativisztikus intenzitás mellett kontrasztfüggő kék-eltolódást mértünk táguló plazmáról, ami ezen a hullámhosszon az eddig mért legmagasabb érték.

\section{Köszönetnyilvánítás}

Ez úton megköszönjük Prof. Dr. Heinrich Horának, a New South Wales Egyetem kutatójának a kísérletek elvégzéséhez az erős motivációt, valamint Bali Krisztiánnak a technikai segítségnyújtást.

A projekt az Európai Unió támogatásával, az Európai Szociális Alap társfinanszírozásával valósul meg. EFOP-3.6.2-16-2017-00005-Ultragyors fizikai folyamatok atomokban, molekulákban, nanoszerkezetekben és biológiai rendszerekben. 


\section{Irodalom}

[1] Obenschain SP, Colombant DG, Schmitt AJ, Sethian JD, McGeoch MW. Phys. Plasmas 13 (2006) https://doi.org/10.1063/1.2198796

[2] Betti R, Zhou C. Phys. Plasmas 12, 110702 (2005)

https://doi.org/10.1063/1.2127932

[3] C. Rödel,M. Heyer, M. Behmke, M. Kübel, O. Jackel, W. Zigler, D. Ehrt, M.C. Klauza, G.G. Paulus; Appl. Phys B. 103: 295-302 (2011)

https://doi.org/10.1007/s00340-010-4329-7

[4] Singh P S, Cui Y Q, Adak A, Lad A D, Chatterjee G, Brijesh P, Sheng Z M \& Kumar R. Sci. Reports 5, 17870 (2016)

https://doi.org/10.1038/srep17870

[5] B. Gilicze, R. Dajka, I. B. Földes, S. Szatmári. Optics Express 25(17), 20791 (2017)

https://doi.org/10.1364/OE.25.020791

[6] S. Szatmári; Appl. Phys. B 58, 211-223 (1994)

https://doi.org/10.1007/BF01081313

[7] B. Gilicze, Zs. Homik, S. Szatmári. Optics Express 27(12):17377-17386 (2019)

https://doi.org/10.1364/OE.27.017377

[8] Zs. Kovács, K. Bali, B. Gilicze, S. Szatmári, I. B. Földes. Phil.Trans.R.Soc. A378, 0043 (2020) https://doi.org/10.1098/rsta.2020.0043

[9] Zs. Kovács, B. Gilicze, S. Szatmári, I. B. Földes. Front. Phys. 8:321. (2020)

https://doi.org/10.3389/fphy.2020.00321

[10] B. Gilicze, A. Barna, Zs. Kovács, S. Szatmári, I. B. Földes. Rev. Sci. Inst. 87, 083101 (2016) https://doi.org/10.1063/1.4960089

[11] R. Fedosejevs, R. Ottmann, R. Sigel, G. Kühnle, S. Szatmári, F. P.Schäfer. Phys. Rev. Lett. 64, 1250-1253 (1990)

https://doi.org/10.1103/PhysRevLett.64.1250

[12] U. Teubner, J. Bergmann, B. Wonterghem, F. P. Schäfer, R. Sauerbrey. Phys. Rev. Lett. 70, 794 (1993)

https://doi.org/10.1103/PhysRevLett.70.794

[13] U. Teubner, P. Gibbon, E. Förster. Physics of Plasmas 3, 2679 (1996)

https://doi.org/10.1063/1.871525

[14] I. B. Földes, J. S. Bakos, K. Gál, Z. Juhász, M. Kedves, G. Kocsis, S. Szatmári, G. Veres Laser Phys. 10, 264-269 (2000)

[15] Ginzburg VL. Oxford, UK: Pergamon. 2nd rev. and encl. ed. 1. (1970)

[16] Brunel F. Phys. Rev. Lett. 59, 52-55 (1987)

https://doi.org/10.1103/PhysRevLett.59.52 
[17] C. Ziener, P. S. Foster, E. J. Divall, C. J. Hooker, M. Hutchinson, A. J. Langley, D. Neely. J. Appl. Phys. 93, 768-770 (2003) https://doi.org/10.1063/1.1525062

[18] R. Sauerbrey. Phys. Plasmas 3, 4712-4716 (1996)

https://doi.org/10.1063/1.872038

[19] S. C. Wilks, W. L. Kruer. IEEE J. Quantum Electron. 33, 1954-1968 (1997) https://doi.org/10.1109/3.641310 